\title{
Hydropic gallbladder in a child due to hepatitis A infection
}

\author{
Bir çocukta hepatit A enfeksiyonuna ikincil gelişen hidropik safra kesesi
}

\author{
Abdullah Barış AKCAN, Senem TUFAN DURSUN, Özgür DEMİRTAŞ, Zafer DÜZGÜN, Şiar DURSUN, Mediha \\ AKCAN, Şevket Şenol AYHAN
}

\begin{abstract}
Hydrops of the gallbladder is rarely seen in childhood and characterized by massive acalculous distension of the gallbladder. It is defined by the absence of calculi, bacterial infection or congenital anomalies of the biliary system. We report a seven year old girl presenting with fever, vomiting,abdominal pain, icterus in scleras, hepatomegaly and tenderness in right hypochondrium. Laboratory investigations revealed hyperbilirubinemia and elevated liver enzymes but there was no evidence of bacterial or parasitic infection. Serology for viral hepatitis suggested acute hepatitis A infection. Abdominal ultrasonography revealed distended, hydropic gallbladder without calculous was observed.

Here we report a child with acute viral acalculous cholecystitis due to hepatitis A virus infection.
\end{abstract}

Keywords: Acalculous cholecystitis, Hepatitis A, Hydrops, Gallbladder

Abdullah Barış Akcan (四)

Sub-department of Neonatology, Department of Child Health and Pediatrics, School of Medicine, Adnan Menderes University, Aydin, Turkey e-mail:barisakc@hotmail.com

Senem Tufan Dursun, Özgür Demirtaş, Zafer Düzgün, Şevket Şenol Ayhan Aydin Gynecology -Obstetrics and Child Health Hospital, Aydın, Turkey

Şiar Dursun, Mediha Akcan

Department of Child Health and Pediatrics, School of Medicine, Adnan

Menderes University, Aydin, Turkey

Submitted/Gönderilme: 26.09 .2015

Accepted/Kabul: 30.10 .2015
ÖZ

Safra kesesi hidropsu, çocukluk çağında seyrek görülen ve safra kesesinin taşsız aşırı distansiyonu ile karakterizedir. Safra kesesi taş1,bakteriyel enfeksiyon veya safra sisteminin kongenital anomalilerinin yokluğu ile karakterizedir. Ateş, kusma, karın ağrıs1, skleralarda ikter, hepatomegali ve sağ hipokondriyumda hassasiyet ile başvuran yedi yaşında bir kız çocuğunu sunduk. Laboratuar incelemeleri, hiperbilirubinemi ve artmış karaciğer enzim düzeylerini göstermekteydi. Bakteriyel veya parazitik enfeksiyon bulgusu yoktu. Viral hepatit serolojisi akut hepatit A enfeksiyonunu göstermekteydi. Abdominal ultrasonografi distandü, hidropik, taşsız safra kesesini göstermekteydi.

$\mathrm{Bu}$ yazımızda, hepatit A virus enfeksiyonu nedeniyle gelişen akut viral taşsız kolesistitli yedi yaşında bir kız çocuğunu sunduk. Anahtar kelimeler: Taşsız kolesistit, Hepatit A, Hidrops, Safra kesesi

\section{Introduction}

Hydrops of the gallbladder (HG) is rarely seen in childhood and characterized by massive acalculous distension of the gallbladder $[1,2]$. It is defined by the absence of calculi, bacterial infection or congenital anomalies of the biliary system. The most consistent clinical features are fever, nausea, vomiting and abdominal pain.

Exposure to hepatitis A virus (HAV) infection occurs at a very early age in endemic areas. Turkey is a moderate endemic area with respect to HAV infection. Acute viral acalculous cholecystitis due to $\mathrm{HAV}$, has rarely been described in children [3] .

Here we report a child with acute viral acalculous cholecystitis due to HAV infection.

\section{Case Report}

A seven-year-old girl admitted with the complaint of fever, abdominal pain, nausea and vomiting for a history of one 
day. She had no previous signs of liver disease. Her parents were not related. Family history was negative for metabolic and inherited liver diseases. There was no significant past medical history. There was no history of medication in the recent past.

Her weight was $21 \mathrm{~kg}$. (10-25 percentile), height 116 $\mathrm{cm}$. (10-25 percentile), temperature $38.5^{\circ}$, blood pressure 95/65 $\mathrm{mm} \mathrm{Hg}$, heart rate 115 beats/min, and respiratory rate $24 \mathrm{ipm}$. She appeared pale, fatigued with mild icterus. Lung and cardiac oscultations were normal. The right side of the abdomen was tender with painful fullness in the right hypochondrium (a positive Murphy's sign). Her liver was palpated $3 \mathrm{~cm}$ below the right costal margins. No splenomegaly was seen.

Laboratory investigation revealed; hemoglobin: 12 g/dL, white blood cell: $10.300 / \mathrm{mm}^{3}$, platelet: $272 \times 10^{9}$ /L, c-reactive protein: $3.2 \mathrm{mg} / \mathrm{dL}(0-5 \mathrm{mg} / \mathrm{dL})$, alanine aminotransferase (ALT): $1198 \mathrm{U} / \mathrm{L}(7-40 \mathrm{U} / \mathrm{L})$, aspartate aminotransferase (AST): $946 \mathrm{U} / \mathrm{L}$ (7-40 U/L), total serum bilirubin: $2.9 \mathrm{mg} / \mathrm{dL}$ with a direct fraction of $1.2 \mathrm{mg} / \mathrm{dL}$, markedly elevated alkaline phosphatase (ALP): 640 U/L (38$155 \mathrm{U} / \mathrm{L}$ ), elevated gamma-glutamyltranspeptidase (GGT): $138 \mathrm{U} / \mathrm{L}$ (15-60 U/L), normal amylase: $38 \mathrm{U} / \mathrm{L}$, albumin: 3.8 $\mathrm{g} / \mathrm{dL}$, prothrombin time: 15.8 seconds and INR : $1.1(\mathrm{~N}: 0.8-$ 1.2). Serology for viral hepatitis suggested acute hepatitis $A$ infection, anti-HAV IgM was positive. Antibodies against hepatitis B,C and E viruses were negative. Serology for salmonellosis and brucellosis were negative. Widal test was non-reactive. Blood and urine culture were sterile. The hydrops of the gallbladder without calculus and hepatomegaly was confirmed by ultrasonography (Figure 1).

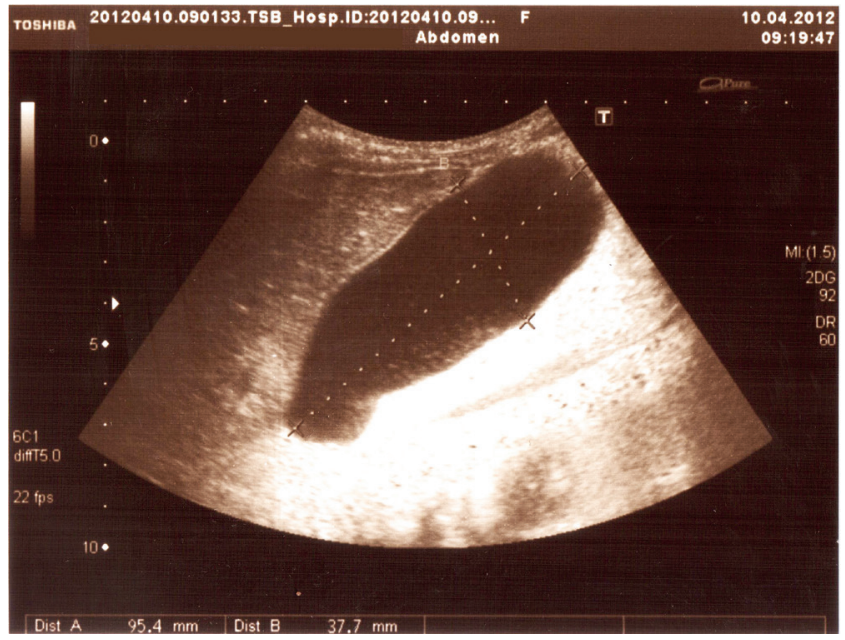

Figure 1. Abdominal ultrasound revealed hydropic gallbladder without calculus.
We stopped oral feeding of the patient and started IV fluid. With conservative management after four days, the patient's condition improved. Her jaundice, abdominal pain, temperature and abdominal tenderness decreased. She started oral feeding at the end of five days. Repeated biochemical study showed, marked decrease in total bilirubin: $0.8 \mathrm{mg} / \mathrm{dL}$ with a direct fraction of $0.5 \mathrm{mg} / \mathrm{dL}$, AST: $79 \mathrm{U} / \mathrm{L}$, ALT: 403 U/L, ALP: $342 \mathrm{U} / \mathrm{L}$, prothrombin time: 12 seconds and INR: 1. Control abdominal ultrasound revealed hepatomegaly and reduced size of gallbladder compared to earlier report. Respectively surgery was not required in our patient. She was discharged on the $9^{\text {th }}$ day of admission and kept under follow-up in our pediatric outpatient department.

\section{Discussion}

Hydrops of the gallbladder is a descriptive clinical term that encompasses the spectrum of noninflammatory and inflammatory acalculous distension of the gallbladder [4]. The symptoms and signs of HG include abdominal pain, vomiting, abdominal mass and/or tenderness. As these clinical features mimic the more common surgical conditions such as acute appendicitis, intussusception and volvulus, some cases are still diagnosed only at laparotomy [1]. The pathophysiology of hydrops of the gallbladder is unknown, but obstruction of the cystic duct and biliary stasis are suggested as the main factors $[1,4]$. The aetiology of acute hydrops of the gallbladder is unknown perhaps multifactorial. Diagnosis is established by ultrasonography of the abdomen demonstrating normal biliary ducts and a distended gallbladder without calculi or congenital malformation. The ultrasonographic criteria for diagnosing acute acalculous cholecystitis (AAC) include (1) gallbladder distention; (2) thickening of the gallbladder wall ( $>3.5 \mathrm{~mm})$; (3) no acoustic shadow or biliary sludge; (4) perivesical liquid accumulation; and (5) no dilatation of the intra- and extrahepatic bile ducts [5].

Ultrasonographic findings in acute viral hepatitis: Hepatomegaly, increase in liver heterogenity, increased periportal echogenity, thickened gallbladder wall and periportal lymphyadenopathy [6] . Gallbladder involvement has been described in 50 to $98 \%$ of adults with acute viral hepatitis, mild gallbladder wall thickening being the most common sonographic finding [7]. However HAV induced HG has been very rarely reported in children $[1,2,6-10]$. Although the origin is obscure, demonstrated invasion of the gallbladder and bile duct epithelium by HAV and cellmediated immunologic response have been proposed in 
the pathogenesis of HAV infection induced cholecystitis $[3,11,12]$. Also HAV associated AAC has complications such as gangrene and perforation [13].

Turkey is moderately endemic in hepatitis A epidemiology $[14,15]$. AAC cases in children should be emphasized for HAV serology in the etiological evaluation.

The treatment of hydrops of the gallbladder varies, depending on the clinical presentation. Most cases are selflimited and the gallbladder may spontaneously decompress with treatment of the underlying systemic disease within approximately two weeks. Associated complications such as gallbladder perforation and deterioration of abdominal signs have been suggested as indications for surgery $[1,4,12,16]$.

Hydrops of gallbladder is a rare complication of HAV infection. Paediatricians and paediatric surgeons must be familiar with the possibility of hydropic gallbladder during HAV infection to avoid unnecessary invasive procedures. Radiologic evaluation must be undertaken for immediate diagnosis as it can lead to surgical emergency.

\section{Conflict of interest}

All authors have no competing interest concerning this article.

Informed consent has been obtained from the parents.

\section{References}

1. Crankson S, Nazer H, Jacobsson B. Acute hydrops of the gallbladder in childhood. Eur J Pediatr 1992;151:318-20. doi: 10.1007/BF02113247

2. Dinulos J, Mitchell DK, Egerton J, Pickering LK. Hydrops of the gallbladder associated with Epstein-Barr virus infection: a report of two cases and review of the literature. Pediatr Infect Dis J 1994;13:924-9.doi: 0891-3668/94/\$03.00/0

3. Casha P, Rifflet H, Renou C, Bulgare JC, Fieschi JB. A calculous acute cholecystitis and viral hepatitis A. Gastroenterol Clin Biol 2000;24: 591-2. doi : GCB-05-200024-5-0399-8320-101019-ART22
4. Gulnar U, Reha C, Akif GM, Bayram O. Hydrops of the gallbladder associated with infection: A report of two cases. Turk J Gastroenterol 2000;11: 84-7.

5. Jeffrey RB Jr, Sommer FG. Follow-up sonography in suspected acalculous cholecystitis: preliminary clinical experience. J Ultrasound Med 1993;12: 183-7.

6. Siegel MJ. Pediatric liver imaging. Semin Liver Dis 2001;21: 251-69. doi: 10.1055/s-2001-15339

7. Sharma MP, Dasarathy S. Gallbladder abnormalities in acute viral hepatitis: a prospective ultrasound evaluation. J Clin Gastroenterol 1991;13: 697-700.

8. Dalgiç N, Ince E, Öncel S, Günes M, Fitöz S, Doğru Ü. Acute viral acalculous cholecystitis due to viral hepatitis A. Ankara Unıv Tip Fak Mecm 2005;58:78-80. doi: 10.1501/ Tipfak 0000000138

9. Souza LJ, Braga LC, Rocha Nde S, Tavares RR. Acute acalculous cholecystitis in a teenager with hepatitis a virus infection: a case report. Braz J Infect Dis 2009;13:74-76. doi: 10.1590/S1413-86702009000100017

10. Aldaghi M, Haghighat M, Dehghani SM. Gallbladder hydrops due to viral hepatitis a infection: a case report. Jundishapur J Microbiol 2015; 8: e15779. doi: 10.5812/jjm.15779.

11. Portincasa P, Moschetta A, Di Ciaula A, et al. Changes of gallbladder and gastric dynamics in patients with acute hepatitis A. Eur J Clin Invest 2001;31: 617-22. doi: 10.1046/j.13652362.2001.00834.x

12. Suresh DR, Srikrishna R, Nanda SK, Annam V, Sunil K, Arjun B. Acalculous gallbladder distension in a young child due to HAV infection: Diagnostic dilemma. Indian J Clin Biochem 2009;24: 316-8. doi: 10.1007/s12291-009-0059-1.

13. Mourani S, Dobbs SM, Genta RM, Tandon AK, Yoffe B. Hepatitis A virus-associated cholecystitis. Ann Intern Med 1994;120:398-400. doi: 10.7326/0003-4819-120-5199403010-00008

14. Türker K, Balcı E, Batı S, Hasçuhadar M, Savaş E. Ülkemizde hepatit A enfeksiyonunun değişen epidemiyolojisi. Türk Mikrobiyol Cem Derg 2011;41:143-8. doi: 10.5222/ TMCD.2011.143

15. Kayaalp C, Ersan V, Yilmaz S. Acute liver failure in Turkey: a systemic review. Turk J Gastroenterol 2014; 25:35-40. doi: 10.5152/tjg.2014.4231

16. Ozaras R, Mert A, Yilmaz MH, et al. Acute viral cholecystitis due to hepatitis A virus infection. J Clin Gastroenterol 2003;37: 79-81. doi: 10.1097/00004836-200307000-00020 